\title{
EFFECT OF INORGANIC NPK FERTILIZER AND BIOORGANIC COMPOST ON GROWTH AND QUALITY OF NUMEX SAHARA BERMUDAGRASS (Cynodon dactylon (L.) Pers.) GROWN IN A SANDY SOIL \\ AbdelKader, H. H. ${ }^{1}$ and A. I. Alhumaid ${ }^{2}$ \\ ${ }^{1}$ Dept. of Vegetables and Floriculture, College of Agric., Mans. Univ., Mans., Egypt. \\ ${ }^{2}$ Dept. of Plant Production and Protection, College of Agric. and Veterinary Medicine, Qassim University, Al-Qassim, Saudi Arabia
}

\begin{abstract}
A field experiment was conducted during the two successive seasons 2007/2008/2009 and 2008/2009/2010 at the Agriculture Experimental Station of the College of Agriculture and Veterinary Medicine, Qassim University, Buraydah, AlQassim, Saudi Arabia. The experiment aimed to study the effects of mineral NPK fertilizer and incorporation of organic compost to the soil on growth and quality of NuMex Sahara Bermudagrass (Cynodon dactylon (L.) Pers.) grown in a sandy soil throughout the year. Seeds were planted on September $15^{\text {th }}$ of 2007 and 2008 for the first and second seasons respectively. In treatments containing compost, compost was incorporated to the top $20 \mathrm{~cm}$ of the soil at two rates; 1 and $3 \mathrm{~kg}$ per square meter, before planting during soil preparation of the beds. Inorganic water soluble NPK fertilizer (14-38-10 +Mg +TE), was applied at three levels; low (100 g/m²/year ), medium (200 $\mathrm{g} / \mathrm{m}^{2} /$ year) , and high $\left(300 \mathrm{~g} / \mathrm{m}^{2} /\right.$ year $)$. The mineral fertilizer was divided into four equal applications (after planting on February of the following year, May, September, and February of the next year). Data included turfgrass establishment (coverage) rate, clippings weight, turfgrass quality, root/shoot ratio, and chlorophyll content, carbohydrates, nitrogen, phosphorus, and potassium $\%$ in the clippings. Data showed that the earliest establishment of NuMex Sahara Bermudagrass was achieved using high NPK (300 g/m²/year ) either alone or combined with 1 or $3 \mathrm{~kg}$ compost incorporated to the soil. These treatments also maintained turfgrass quality above the acceptable level throughout the entire season, including late fall and winter. The best results for growth, quality, and all previously mentioned measurements were obtained by applying $300 \mathrm{~g} / \mathrm{m}^{2} /$ year NPK fertilizer divided to 4 equal applications to Bermudagrass grown in the soil incorporated with $3 \mathrm{~kg}$ of the bioorganic compost during soil preparation.
\end{abstract}

\section{INTRODUCTION}

Turfgrasses used for home lawns, commercial landscapes, athletic fields, and golf courses improve quality of life by providing open space, recreational and business opportunities, enhanced property values, and the conservation of important natural resources (Duble, 2010).

The sand-based profiles are usually used in the construction of sports fields and golf course turfgrasses in order to limit compaction and to provide sufficient drainage, but these systems lack water-retention and nutrient holding capacity necessary for healthy turf growth (Bigelow et al., 2001). Sandy soils, are poor in mineral, and organic colloids with low fertility as determined by the shortage of macro- and micronutrients (Weber et al., 
2007). In oreder to keep turf and landscapes functional and aesthetically pleasing, turfgrasses rely heavily on pesticides and proper fertilizer programs (Voigt et al., 2006). The primary mineral nutrients used in fertilizer programs are nitrogen $(\mathrm{N})$, phosphorus $(\mathrm{P})$, potassium $(\mathrm{K})$, and iron $(\mathrm{Fe})$, respectively (Starrett et al., 1995).

Nitrogen is the key element in turfgrass fertility programs and is required in greatest quantities by turfgrasses since it influences healthy growth, color and density (Hull, 1996). New lawns have a limited root system and require higher levels of phosphorus for healthy seedling development (Landschoot and Waddington, 1987). Potassium is important in improving stress tolerance (such as heat, cold, and wear disease) of turfgrasses and is essential to plant growth (Snyder and Cisar, 2000).

Sandy soils, such as used in athletic fields and golf greens, have been shown to result in high movement of nitrate- $\mathrm{N}$ to subsurface waters (Marshall et al., 2001 and Shuman, 2002), and the amounts of $\mathrm{N}$ and/or $\mathrm{P}$ applied in excess of what the plants can use, move into ground water by leaching, thereby becoming an environmental hazard (Weber et al., 2007).

The physical properties of sandy soils which are the crucial factors determining plant growth depend mainly on the amount of organic matter (Franzluebbers, 2002). Peat moss was the most commonly soil amendment incorporated into the sandy soil used for turfgrasses, but it breaks down, over time, into fine particles and reduces water infiltration rates and loses some of its nutrient retention capacity (Bigelow et al., 2004).

Studies have shown that organic compost can enhance turfgrass establishment and quality compared with fertilizer sources of nutrients (Cisar and Snyder, 1992; Garling and Boehm, 2001; Loschinkohl and Boehm, 2001; Landschoot and McNitt, 1994).

Compost enhances physical structure of soil (Ginting et al., 2003), makes it more efficient in water utilization, modifies and stabilizes the $\mathrm{pH}$ of the soil (Wright et al., 2008), increases cation exchange capacity, provides nutrients in a slow release (Chantigny et al., 2002), and provides organic matter to soil organisms (Wright et al., 2008).

Bermudagrass (Cynodon spp.) is one of the most widely used grasses on athletic fields and golf courses in the warm humid and warm semi-arid regions of the world and grows on a wide range of soil types as long as there is adequate drainage and plenty of sunlight (Beard, 1973). NuMex Sahara Bermudagrass (Cynodon dactylon (L.) Pers. ) was developed exclusively for turf. Sahara was released in 1988 after over 20 years of research, and was bred by Dr. Arden Baltensperger of Seeds West, Inc. (www.allaboutturf.com). Compared to common Bermudagrass, Sahara is more uniform, has increased density and improved summer green color. In addition, Sahara is superior in drought tolerance to common and many other Bermudagrass varieties (www.Bermudagrass.com).

This research aimed to study the effects of mineral NPK fertilizer and incorporation of organic compost to the soil on growth and quality of NuMex Sahara Bermudagrass (Cynodon dactylon (L.) Pers.) grown in sandy soil throughout the year. 


\section{MATERIALS AND METHODS}

This experiment was carried out during the two successive seasons 2007/2008/2009 and 2008/2009/2010 at the Agriculture Experimental Station of the College of Agriculture and Veterinary Medicine, Qassim University, Buraydah, Al-Qassim Province, Saudi Arabia (Latitude 26 $36^{\circ}$ 'North, Longitude $43^{\circ} 97^{\prime}$, and 608 meters elevation above sea level). The experimental soil analysis is shown in Table 1. Water used was well water with a $7.11 \mathrm{pH}, 945 \mathrm{ppm}$ TDS, and 2.66 'SAR'.

Table (1): Soil analysis of the experimental area.

\begin{tabular}{|c|c|c|c|c|c|c|c|c|c|}
\hline \multicolumn{10}{|c|}{ Chemical properties } \\
\hline \multirow[b]{2}{*}{$\mathrm{pH}$} & \multirow[b]{2}{*}{ EC } & \multicolumn{3}{|c|}{$\begin{array}{l}\text { Slouble cations } \\
\left.\text { (meq. } L^{-1}\right)\end{array}$} & \multicolumn{3}{|c|}{$\begin{array}{l}\text { Soluble anions } \\
\left.\text { (meq. } L^{-1}\right)\end{array}$} & $\mathrm{Ca} \mathrm{CO}_{3}$ & $\begin{array}{l}\text { Organic } \\
\text { matter }\end{array}$ \\
\hline & & \multicolumn{2}{|c|}{$\mathrm{Na}^{+} \quad \mathrm{Ca}^{2+}$} & $\mathbf{M g}^{2+}$ & \multirow{2}{*}{$\frac{\mathrm{HCO}_{3}^{-}}{2.5}$} & \multirow{2}{*}{$\frac{\mathrm{SO}_{4}{ }^{2-}}{11.7}$} & \multirow{2}{*}{$\frac{\mathrm{Cl}^{-}}{7.6}$} & \multicolumn{2}{|c|}{$\%$} \\
\hline 8.2 & 2.1 & 11 & 4.55 & 2.2 & & & & 3.2 & 0.23 \\
\hline \multirow{2}{*}{\multicolumn{2}{|c|}{$\begin{array}{l}\text { Available } \\
\text { NPK (ppm) }\end{array}$}} & \multicolumn{3}{|c|}{$\mathrm{N}$} & \multicolumn{3}{|c|}{$\mathrm{P}$} & \multicolumn{2}{|c|}{$\mathrm{K}$} \\
\hline & & \multicolumn{3}{|c|}{5.4} & \multicolumn{3}{|c|}{4.8} & \multicolumn{2}{|c|}{119} \\
\hline \multicolumn{10}{|c|}{ Physical properties } \\
\hline \multicolumn{6}{|c|}{ Fractions (\%) } & \multirow{2}{*}{\multicolumn{4}{|c|}{ Texture }} \\
\hline & & & & \multirow{2}{*}{\multicolumn{2}{|c|}{$\frac{\text { Clay }}{1.1}$}} & & & & \\
\hline \multicolumn{2}{|c|}{95.3} & \multicolumn{2}{|c|}{3.6} & & & \multicolumn{4}{|c|}{ Sandy soil } \\
\hline
\end{tabular}

In each season, the experiment was set up in different areas and followed the same procedures. In each season, the soil of the experimental area was watered thoroughly and all vegetations showed for up to 3 weeks before planting and later throughout the experiment weeds were removed manually. The experimental soil was then ploughed thoroughly, and afterwards raked and dragged to smooth the soil surface. The experimental design was set up as a randomized complete block design with three replicates, each consisted of 12 planting beds. Each bed was $1 \times 1.5 \mathrm{~m}$, and the beds were spaced one meter apart. A sprinkler irrigation system was set up for each experimental area and was controlled manually. In treatments containing compost, compost was incorporated to the top $20 \mathrm{~cm}$ of the soil at two rates; 1 and $3 \mathrm{~kg}$ per square meter, before planting during soil preparation of the beds. A bioorganic compost was used in this experiment; a product of Protein Organic Compost Inc., Riyadh, Saudi Arabia. The composition of the compost is shown in Table (2) (according to the company label). After compost was incorporated, soil samples were tested at the Soil Science Laboratory for soil $\mathrm{pH}$ and EC, and the water holding capacity of the soil samples was measured geometrically (data shown in Table, 3 ). 
Table (2): Analysis of the bioorganic compost used.

\begin{tabular}{|c|c|c|c|c|c|c|c|}
\hline Organic & Moisture & \multicolumn{6}{|c|}{$\%$} \\
\hline \multicolumn{2}{|c|}{$\%$} & $\mathbf{N}$ & $\mathbf{P}$ & $\bar{K}$ & $\mathrm{Mg}$ & $\mathrm{Ca}$ & $\mathrm{Na}$ \\
\hline 45.6 & 8.52 & 1.647 & 1.39 & 0.9 & 0.272 & 1.527 & 0.016 \\
\hline & & \multicolumn{6}{|c|}{ ppm } \\
\hline EC & 6.03 & $\mathrm{Al}$ & $\mathrm{Mn}$ & $\mathrm{Fe}$ & $\mathrm{Cu}$ & $\mathrm{Zn}$ & $\mathrm{Cl}$ \\
\hline $\mathrm{pH}$ & 7.21 & \multirow[t]{2}{*}{175} & \multirow[t]{2}{*}{55.1} & \multirow[t]{2}{*}{173.7} & \multirow[t]{2}{*}{4.3} & \multirow[t]{2}{*}{24.3} & \multirow[t]{2}{*}{470} \\
\hline $\mathrm{C} / \mathrm{N}$ & $30: 1$ & & & & & & \\
\hline
\end{tabular}

Table (3): Water holding capacity (\%), EC, and pH of the experimental soil with or without compost.

\begin{tabular}{|c|c|c|c|}
\hline & Soil & $\begin{array}{c}\mathbf{1} \mathbf{k g} \text { compost } \\
\mathbf{/ m}^{2} \text { soil }\end{array}$ & $\begin{array}{c}\mathbf{3 k g} \text { compost } \\
\mathbf{/ m}^{2} \text { soil }\end{array}$ \\
\hline Water holding capacity \% & 35.6 & 36.28 & 38.5 \\
\hline EC & 2.1 & 2.9 & 3.9 \\
\hline $\mathrm{pH}$ & 8.2 & 8.04 & 7.85 \\
\hline
\end{tabular}

NuMex Sahara bermuda grass Cynodon dactylon (L.) Pers. (thiram treated) seeds from Al Centro Seed Company, California, USA, imported by ARZAM Agricuttture and Trading Inc., Riyadh, Saudi Arabia was used in this experiment.

Seeds were planted on September $15^{\text {th }}$ of 2007 and 2008 for the first and second seasons respectively. Seeds were planted at the rate of $1 \mathrm{~kg}$ seeds $/ 30 \mathrm{~m}^{2}$ area, evenly broadcasted over the soil and lightly incorporated using a rake. Immediately after planting, the beds were thoroughly watered, and thereafter twice a day until emergence. After emergence, beds were watered as needed depending on the environmental and soil conditions. Inorganic water soluble NPK fertilizer (14-38-10 +Mg +TE), a product of SABEC, Saudi Arabic was applied at three levels; low (100 g/m²/year), medium (200 g/m²/year), and high (300 $\mathrm{g} / \mathrm{m}^{2} /$ year) to the turfgrass. The mineral fertilizer was divided into four equal applications (after planting in February of the following year, May, September, and February of the next year).

Measurements:

1-Rate of Establishment: was measured as the percentage of area fully covered with the turfgrass of the total area of each plot. This measurement was assessed starting from February $1^{\text {st }}$ of the following year in each season (from February 2008 until May 2008 for the first season and from February 2009 until May 2009 for the second season).

2-Fresh weight of clippings: starting from May $1^{\text {st }} 2008$ until end of May 2009 in the first season and from May 1 1st 2009 until end of May 2010 in the second season, the turfgrasses were hand cut clipped once or twice a month (depending on the turfgrass growth ) throughout the experiment and the fresh weight of clipping was recorded as fresh weight $(\mathrm{g})$ per $\mathrm{m}^{2}$ per month. 
3-Turf quality: each month, turf quality was visually scored (According to Alshammary et al., 2004) on a scale of $1-9$, based on density, uniformity and color, where $9=$ ideal green, dense, and uniform turf, and $1=$ completely dead or dormant brown/yellowish colored turf. Any value below 5 was considered as unacceptable quality.

4-Root/shoot ratio : was measured as dry weight of below-ground portion divided by the dry weight of the above-ground portion of the turfgrass. At the end of May 2009 and 2010 in the first and second seasons, respectively, profile samples were randomly collected from three different spots in each plot using a standard green cup cutter with $10 \mathrm{~cm}$ diameter to a depth of $25 \mathrm{~cm}$. Plugs were washed to obtain soil free, and all the aboveground plant material were excised from the top of the plug with a scissor at the thatch-soil level. Stolons were included with the above-ground portion, while rhizomes were with the below-ground portion. The fresh weight of each portion was weighed, dried in an oven at $70^{\circ} \mathrm{C}$ for three days, and their dry weights were recorded.

5-Chemical analysis: samples for chemical analysis were collected at the end of May the next year in each season. Clippings were collected and analyzed for the following determinations:

a.Chlorophyll content: was determined in the fresh clippings according to the method described by Marquard and Timpton, (1987).

b.Total carbohydrates (\%) was determined in the clippings dried samples using the method described by Dubois et al., (1956).

c. $\mathbf{N}, \mathbf{P}$, and $\mathbf{K}(\%)$ : dried clipping samples were used to determine nitrogen (\%) using Micro-Kjeldahll , and phosphorus and potassium (\%) using flame photometer according to the methods described by Jackson, (1973).

Statistical analysis:

The experimental design was set up as a randomized complete block design with three replicates, each consisted of 12 planting beds. Treatments were as follows:

Control: neither compost nor fertilizer added.

C1: low compost (1 kg compost incorporated to the soil).

C2: high compost (3 $\mathrm{kg}$ compost incorporated to the soil).

M1: low inorganic fertilizer (100 g NPK $/ \mathrm{m}^{2} /$ year).

M2: medium inorganic fertilizer (200 g NPK $/ \mathrm{m}^{2} /$ year).

M3: high inorganic fertilizer (300 $\mathrm{g} \mathrm{NPK} / \mathrm{m}^{2} /$ year).

M1+C1: low inorganic fertilizer + low compost.

M1+C2: low inorganic fertilizer + high compost.

M2+C1: medium inorganic fertilizer + low compost.

M2+C2: medium inorganic fertilizer + high compost.

$\mathbf{M} 3+\mathbf{C} 1$ : high inorganic fertilizer + low compost.

M3+C2: high inorganic fertilizer + high compost.

The experiment was analyzed as a randomized complete block design with three replicates. Analysis of variance was performed using SAS 
software (SAS, 1998). Treatment means were compared using LSD at the 5 $\%$ probability.

\section{RESULTS AND DISCUSSION}

For the sake of convenience, any record represented in graphics was split into two separate graphics (A\&B); the first $(A)$ represented individual treatments, and the second (B) represented the combined treatments.

Turfgrass establishment:

The establishment rate measured as percentage of area covered with Bermudagrass during $t$ following spring after sowing in the first season (Fig $1 \mathrm{~A}$ and $1 \mathrm{~B}$ ) showed that high NPK treated plots by April $1^{\text {st }}$ achieved $100 \%$ establishment, and by May all NPK fertilized plots and those planted in high compost (C2) plots reached $100 \%$ coverage. As for the combined treatments (Fig 1B), early establishment ( on April) was achieved using high NPK (M3) treatment combined with either compost treatments (C1 or C2) and medium NPK (M2) combined with high compost treatment (C2). In the second season (Fig 2A), early establishment on April was achieved using high and medium NPK treatments. In addition, all combined treatments (Fig 2B) achieved full establishment by April except for low NPK combined with low compost. These results showed that increasing NPK dose especially when combined with high compost incorporated to the soil strongly encouraged growth and establishment of Bermudagrass.

The results agree with previous research which showed that increasing inorganic fertilization enhance establishment of turfgrasses (Geron et al., 1993 and Grigg, 1999). Also studies have shown that the amendments with organic compost can enhance turfgrass establishment (Angle et al., 1981; Cisar and Snyder, 1992; Garling and Boehm, 2001; Landschoot and McNitt, 1994). Thus, the combined effects of both high NPK fertilization with organic amendments would result in more effect on turfgrass establishment.

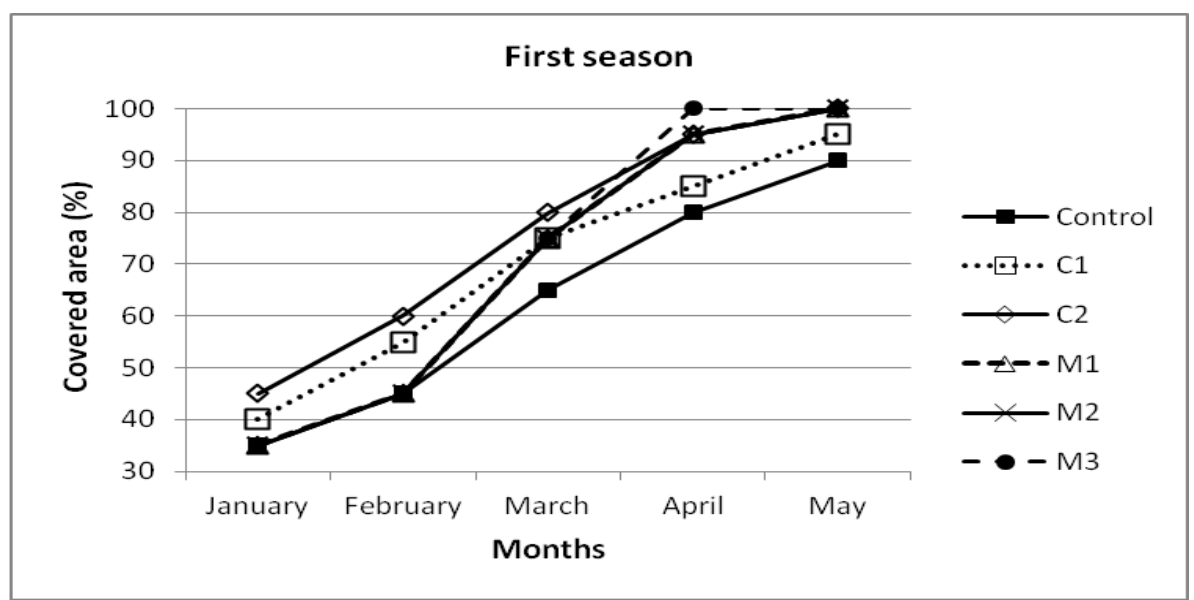

Figure (1A): Establishment rate of Bermudagrass treated with different individual treatments at the beginning of 2008 season. 


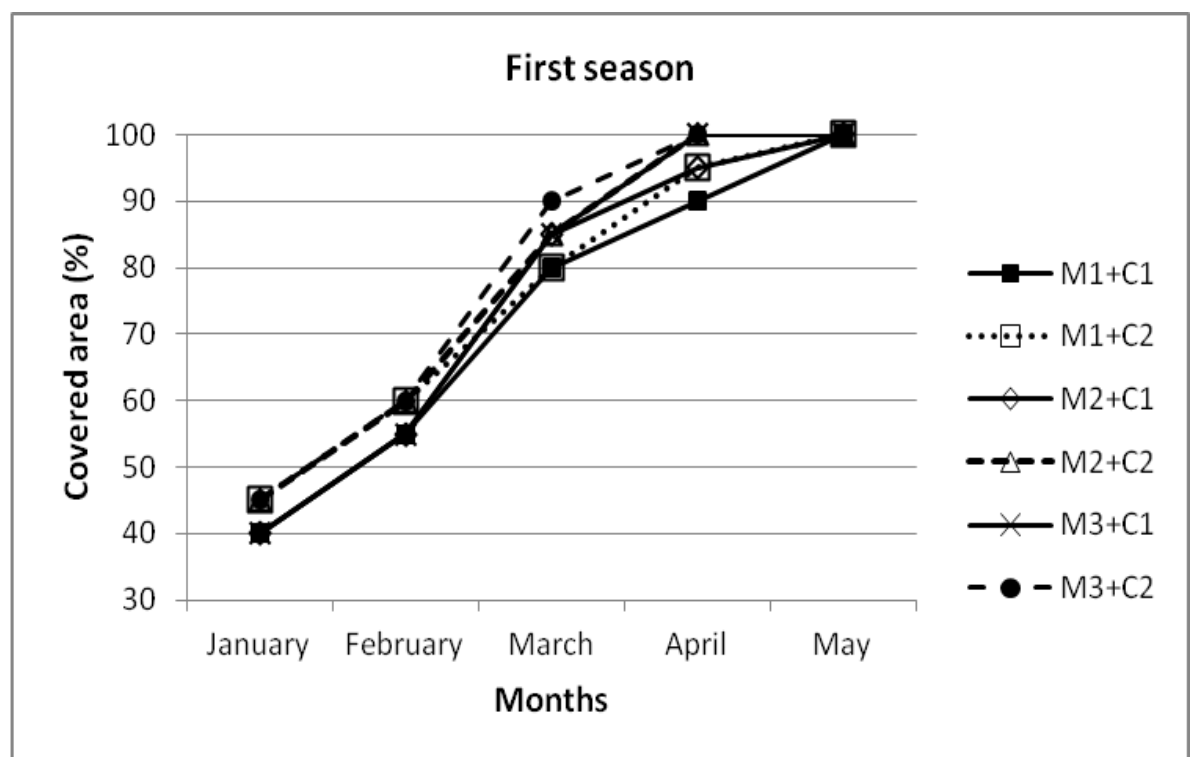

Figure (1B): Establishment rate of Bermudagrass treated with different combined treatments at the beginning of 2008 season.

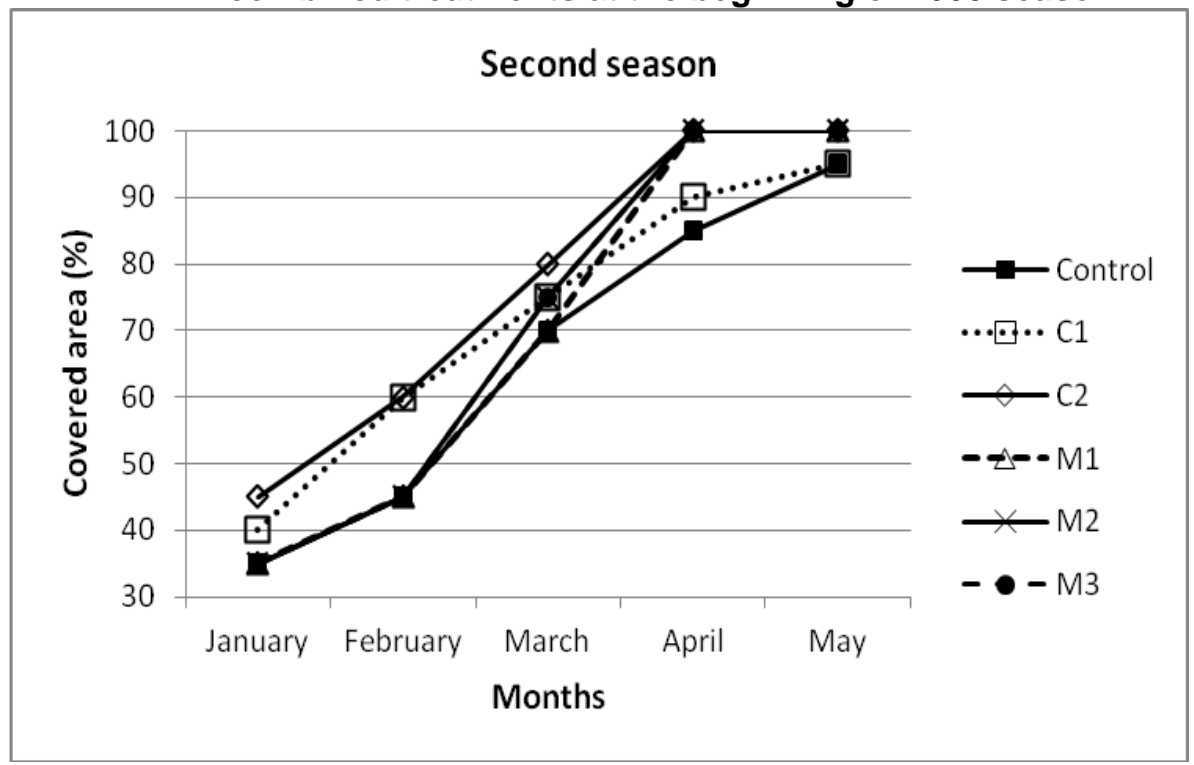

Figure (2A): Establishment rate of Bermudagrass treated with different individual treatments at the beginning of 2009 season. 
AbedelKader, H. H. and A. I. Alhumaid

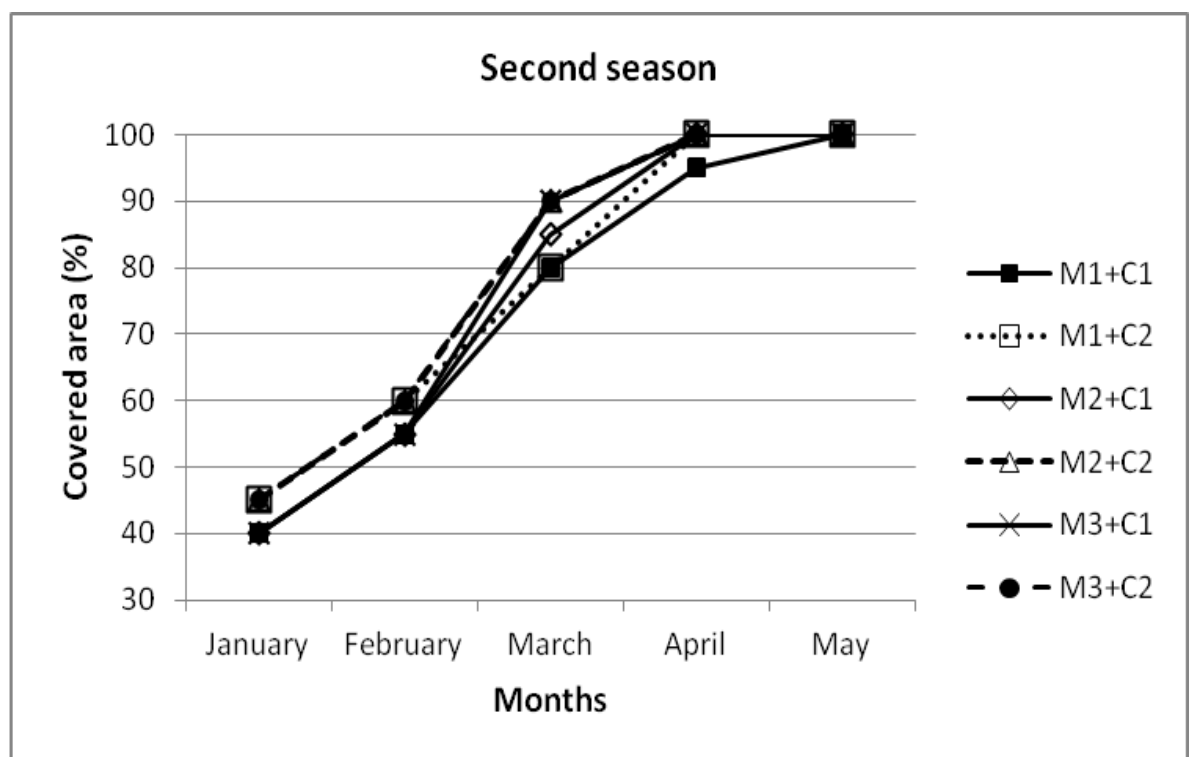

Figure (2B): Establishment rate of Bermudagrass treated with different combined treatments at the beginning of 2009 season.

\section{Turfgrass growth and Quality:}

Clippings fresh weight in the first season increased from May until fall, then started to decrease during late fall and winter to the lowest level by January, and start to increase again by March until the following May. In both seasons, among single treatments (Fig $3 A$ \& $4 A$ ), plots which received high NPK treatment (M3) resulted in the highest fresh weight of clippings, followed by those received medium NPK fertilizer treatment(M2) . The trend through the months was very much similar among combined treatments (Fig 3B \& 4B), and the highest clippings fresh weight was achieved when high NPK fertilizer treatment was combined with high compost treatment $(M 3+C 2)$, followed by that combined with low compost treatment $(\mathrm{M} 3+\mathrm{C} 1)$, then medium NPK combined with high compost treatment (M2+C2). 


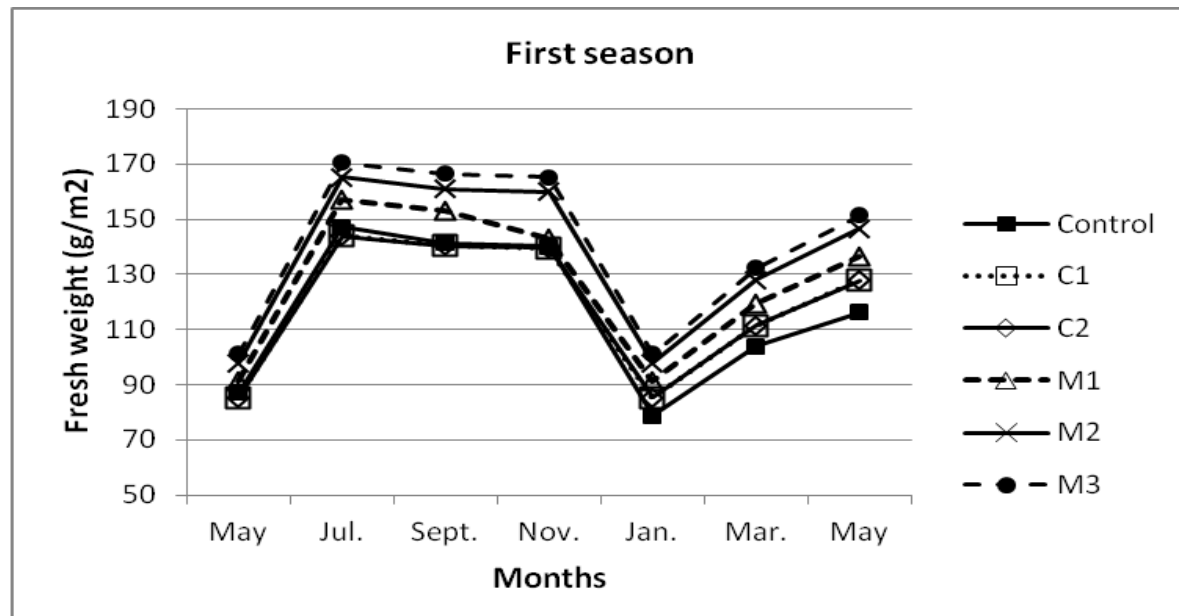

Figure (3A): Clippings fresh weight of Bermudagrass treated with different individual treatments during 2008/2009 season.

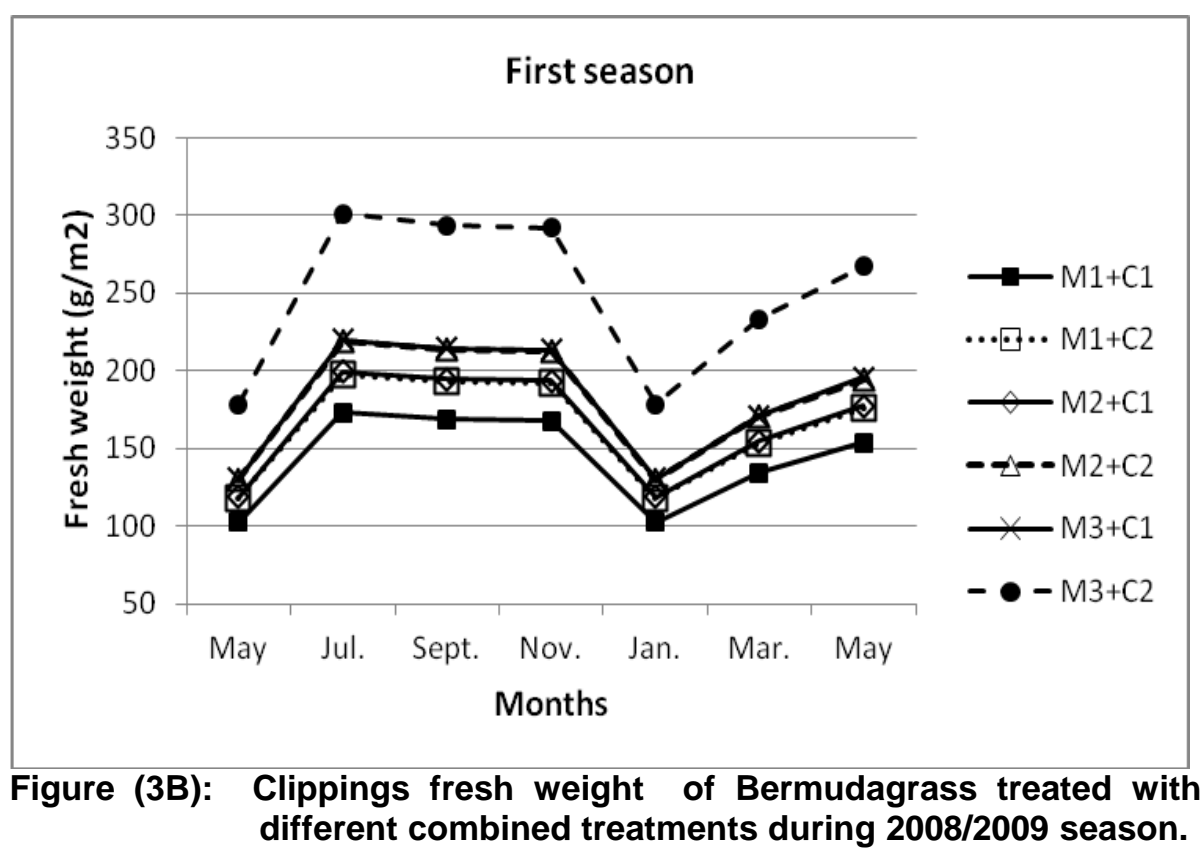




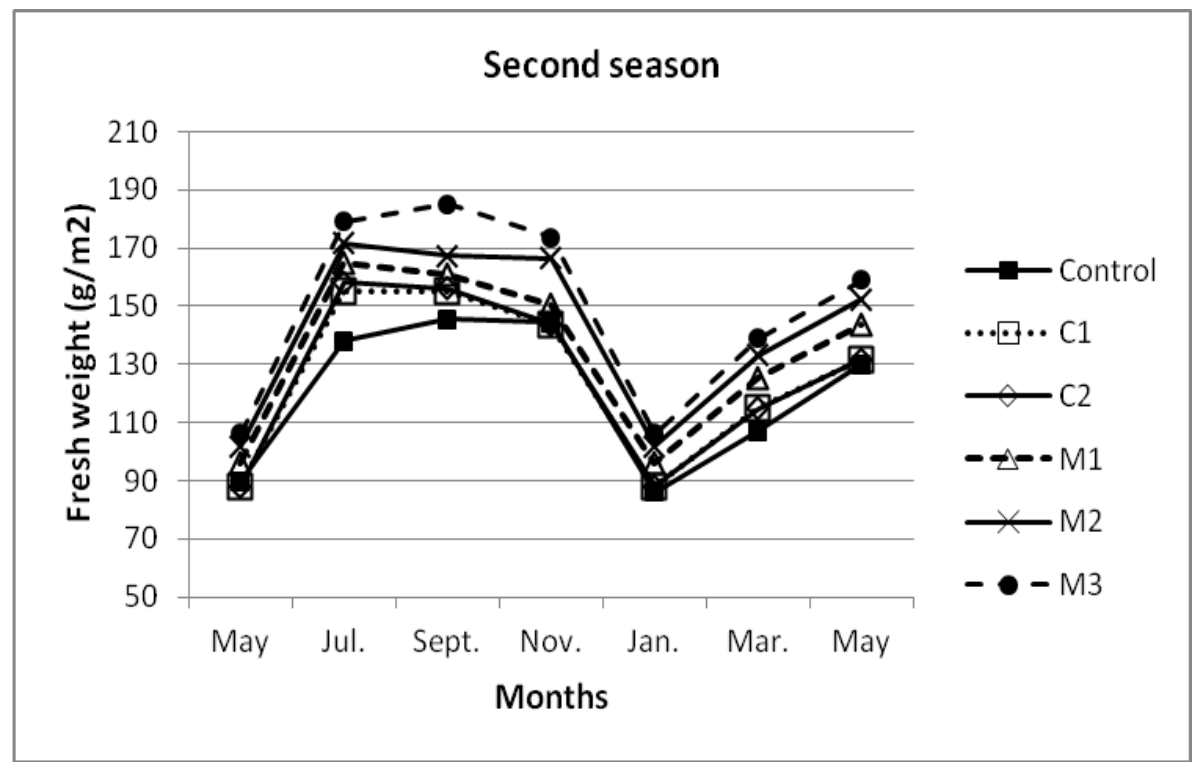

Figure (4A): Clippings fresh weight of Bermudagrass treated with different individual treatments during 2009/2010 season.

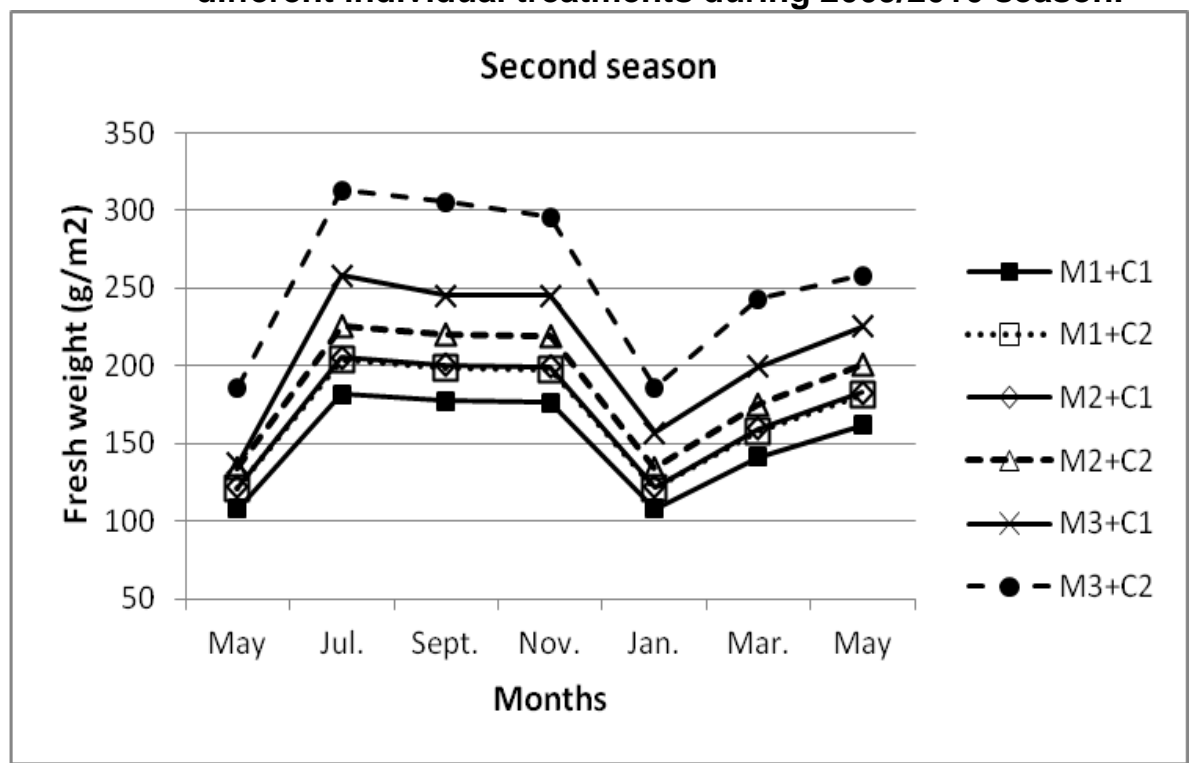

Figure (4B): Clippings fresh weight of Bermudagrass treated with different combined treatments during 2009/2010 season.

In both seasons, the quality rating of Bermudagrass treated with single treatments (Figures $5 A \& 6 A$ ) showed that the quality rating of Bermudagrass had highest scores during September until November, then dropped during winter to unacceptable values. Through the following spring, 
Bermudagrass started to regain its quality and, by May, were all above the acceptable level. Plots fertilized with high NPK level (M3) had highest quality score than all other single treatments throughout the year. The quality ratings of Bermudagrass treated with combined treatments showed a similar trend (Figures 5B \&6B), but quality of all treatments were acceptable during winter. However, high NPK fertilization combined with high compost treatment $(\mathrm{M} 3+\mathrm{C} 2)$ averaged better quality than other combined treatments. This indicates the importance of both high NPK fertilization and high compost to improving and preserving the quality of Bermudagrass even during winter months.

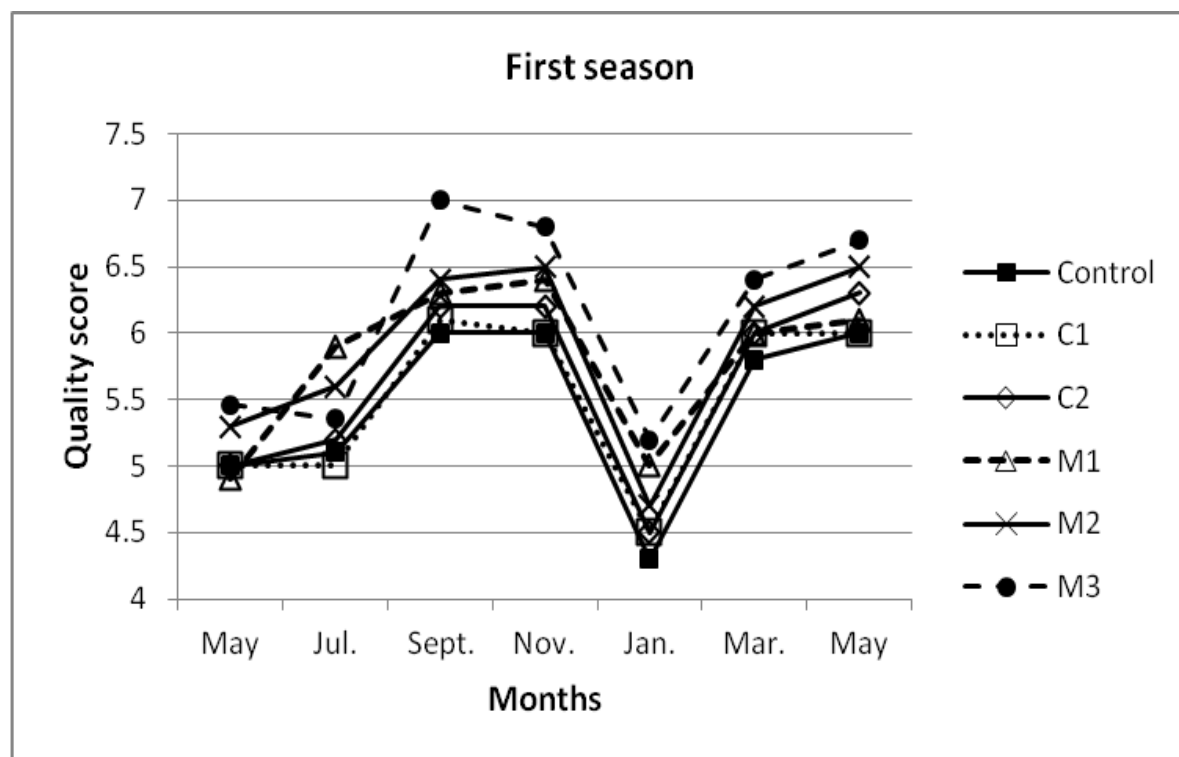

Figure (5A): Quality of Bermudagrass treated with different individual treatments during 2008/2009 season. 
AbedelKader, H. H. and A. I. Alhumaid

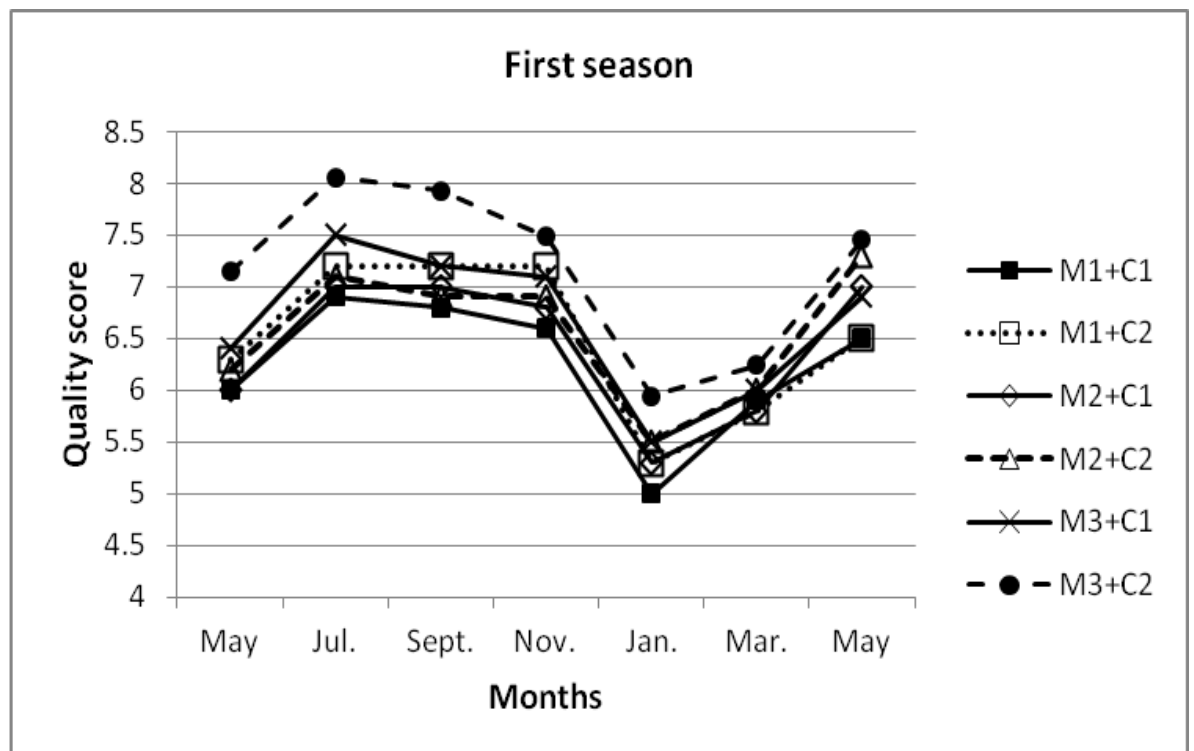

Figure (5B): Quality of Bermudagrass treated with different combined treatments during 2008/2009 season.

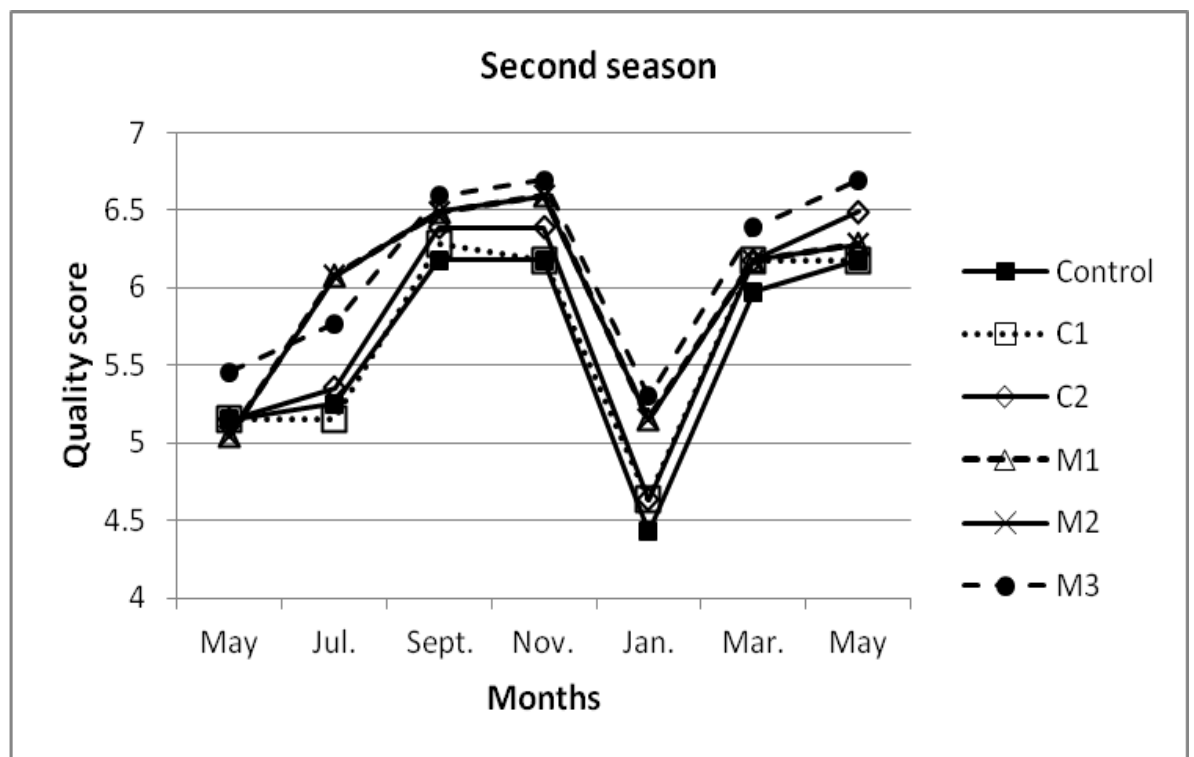

Figure (6A): Quality of Bermudagrass treated with different individual treatments during 2009/2010 season. 


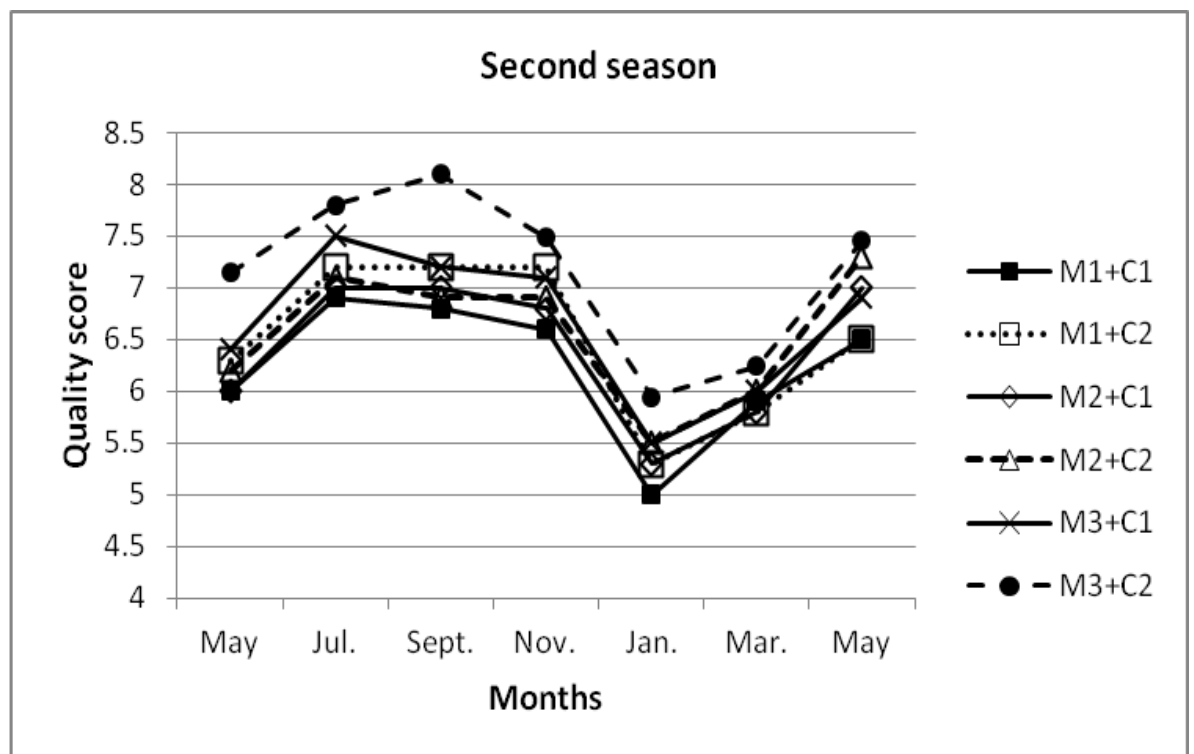

Figure (6B): Quality of Bermudagrass treated with different combined treatments during 2009/2010 season.

The growth behavior throughout the experiment months is typical, since Bermudagrass is a warm season perennial species that grows best under extended periods of high temperatures and mild winters, makes the best growth where average daily temperatures are above $75^{\circ} \mathrm{F}\left(23.9^{\circ} \mathrm{C}\right)$, and the optimum daytime temperature for Bermudagrass is between $95^{\circ}$ and $100^{\circ} \mathrm{F}\left(35\right.$ to $\left.38^{\circ} \mathrm{C}\right)$ (Beard, 1973). Research has demonstrated that when average temperatures drop below $50^{\circ} \mathrm{F}\left(10^{\circ} \mathrm{C}\right)$, growth stops, and the grass begins to discolor, until the average daily temperatures rise above $50^{\circ} \mathrm{F}(10$ ${ }^{\circ} \mathrm{C}$ ) for several days in the following spring (Duble, 2010).

Sandy soils, are poor in mineral and organic colloids, and have low fertility as determined by a shortage of macro- and micronutrients (Weber et al., 2007). The addition of essential minerals in the form of soluble NPK would supply the turfgrass with nutrients required for growth and development, and results showed that the higher the rate of fertilizer, the more the growth and the better quality of Bermudagrass were acheived. In this concern, Razmjoo and Kaneko, (1993) suggested that a well- balanced fertility ratio and rate of the NPK fertilizer used for turfgrasses are the key to prevent dormancy and promote growth and improve quality. Callahan and Overton, (1978) reported a significant increase in 'Common' Bermudagrass density when $\mathrm{N}$ was increased from 10 to $20 \mathrm{~g} \mathrm{~m}^{-2} \mathrm{y}^{-1}$. In addition, Paswan and Machahary, (2000) showed that increasing $N$ rate from 0 to $40 \mathrm{~g} / \mathrm{m}^{2}$ increased shoot length, fresh weight $\left(\mathrm{g} / \mathrm{m}^{2}\right)$ and quality score of bahiagrass. Moreover, Van Auken and Bush, (1997) reported that, addition of $\mathrm{P}$ and $\mathrm{N}$ together to native 
soil increased above- and belowground dry mass 2.9-6.5 times in Paspalum plicatulum.

Physical characteristics of sandy soils, as well as their other fertility factors, depend mainly on the amount of organic matter (Franzluebbers, 2002 ).

The chemical analysis of the soil in this experiment showed that adding compost to the soil increased water holding capacity and lowered $\mathrm{pH}$ of the soil (Table, 3). Organic manure increased structural stability and water retention of sandy soils (Ginting et al., 2003), and caused a decrease in the soil pH (Habteselassie et al., 2006; Sims, 1990; Wright et al., 2008), near neutral $\mathrm{pH}$ values (6.5-8.1), which represent a range favorable for turfgrass root growth (Landschoot, 1996).

The chemical composition of the bioorganic compost used in this experiment revealed that it contained considerable amount of nutrients (Table, 2 ). Previous results indicated that, application of composts and organic amendments increases soil nutrient levels (Chantigny et al., 2002; Gregorich et al., 1998), which is often attributed to the presence of soluble materials in composts (Chantigny et al., 2002).

Thus, adding compost to sandy soil during soil preparation and the addition of NPK fertilizer resulted in better growth and quality of Bermudagrass. Early reports by Sikora et al., (1980) showed that clipping yields of all fescue were increased further when inorganic fertilizer $(\mathrm{N}, \mathrm{P}$, or $\mathrm{N}$ $+\mathrm{P}$ ) was applied with compost. The largest increases were associated with turf treated with both compost and supplemental $\mathrm{N}+\mathrm{P}$.

The average clipping fresh weight per month (Table, 4) showed that the highest NPK plus high compost application (M3+C2) resulted in the highest average fresh weight of clippings per months, followed by $(\mathrm{M} 3+\mathrm{C} 1)$. All NPK single treatments (M3,M2, and M1) gave higher average fresh weight of clippings than either compost treatments alone ( $\mathrm{C} 1$ or $\mathrm{C} 2)$. The highest average fresh weight of clippings was that of highest NPK fertilizer combined with high compost $(\mathrm{M} 3+\mathrm{C} 2)$. High NPK fertilizer treatment combined with low compost $(\mathrm{M}+\mathrm{C} 1)$, medium NPK fertilizer combined with high compost $(\mathrm{M} 2+\mathrm{C} 1)$, and high NPK fertilizer alone (M3) treatments ranked second among all treatments and were not significantly different among each other. These results indicated that high NPK fertilizer was the key to improving growth of Bermudagrass especially when combined with high compost incorporated to the sandy soil. The largest increases in clipping yields were associated with turf treated with both compost and supplemental $\mathrm{N}+\mathrm{P}$ (Sikora et al., 1980; Tester et al., 1982; Tester, 1989).

In addition, Sakr et al. (2008) reported that combining sewage sluge compost $(0.01 \mathrm{~m} 3 / \mathrm{m} 2)$ with the highest rate of conventional NPK fertilizer $(55.6 \mathrm{~g} / \mathrm{m} 2 / \mathrm{month})$ resulted in the highest values for vegetative growth parameters of Zoysia japonica turfgrass grown in sandy soil, and recommended that the soil should be amended with sewage sludge compost $\left(0.01 \mathrm{~m}^{3} / \mathrm{m}^{2}\right)$ during soil preparation, and the plants should be supplied with $55.6 \mathrm{~g} / \mathrm{m}^{2} /$ month of the conventional NPK fertilizer $\left(9 \% \mathrm{~N}-5 \% \mathrm{P}_{2} \mathrm{O}_{5}-5 \% \mathrm{~K}_{2} \mathrm{O}\right)$. 
Root/shoot ratio, chlorophyll content, and quality:

The highest significant root/shoot ratio, chlorophyll content, and quality score at the end of the experiment (Table, 4) were those of Bermudagrass planted in high or low compost incorporated soil and received high NPK treatment $(\mathrm{M} 3+\mathrm{C} 2$ and $\mathrm{M} 3+\mathrm{C} 1)$. Treatments received medium or low NPK plus compost or high NPK alone ranked second. This indicates that compost addition to the soil had positive effect on root growth and quality of Bermudagrass.

Similarly, Paswan and Machahary, (2000) reported that increasing $N$ rate from 0 to $40 \mathrm{~g} / \mathrm{m}^{2}$ increased leaf chlorophyll content and nitrogen content of shoot tissue of Paspalum notatum. Also, Schumann et al., (1993) observed enhanced color of tall fescue (Festuca arundinaceae Schreb.) and a Kentucky bluegrass (Poa pratensis L.)-perennial ryegrass (Lolium perenne L.) mixture following the application of composted biosolids. NPK fertilizer encourages the growth and quality of turfgrasses. Nitrogen is the key element in turfgrass fertility programs since it influences healthy growth, color and density (Hull, 1996). Nitrogen (N) requirements to maintain good quality of Tifway Bermudagrass was reported by Carrow et al., 1987 to be at least 20 to $30 \mathrm{~g} \mathrm{~N} \mathrm{~m}^{-2} \mathrm{yr}^{-1}$. Totten, (2007) stated that clipping yield and turf quality ratings of Bermudagrass, were significantly higher at $254 \mathrm{~kg} \mathrm{~N} \mathrm{ha}^{-1} \mathrm{yr}^{-1}$, compared to $190 \mathrm{~kg} \mathrm{~N} \mathrm{ha}^{-1} \mathrm{yr}^{-1}$. Additionally, Callahan and Overton (1978) reported a significant increase in 'Common' Bermudagrass density when $\mathrm{N}$ was increased from 10 to $20 \mathrm{~g} \mathrm{~m}^{-2} \mathrm{y}^{-1}$.

New lawns have a limited root system and require higher levels of phosphorus for healthy seedling development (Voigt et al., 2006). Potassium is important in improving stress tolerance (such as heat, cold, and wear disease) of turfgrasses and is essential to plant growth (Snyder and Cisar, 2000). Recommended rates of fertilization for establishment of seashore paspalum are 98 to $147 \mathrm{~kg}$ ha-1 of phosphorus and potassium for root establishment and rhizome and stolon growth, and spoon feeding nitrogen with 24 to $49 \mathrm{~kg} \mathrm{ha}^{-1}$ on a two to six week schedule (Trenholm et al., 2001).

Angle et al., (1981) showed that the quality of the turf increased with both time and the compost amendment rate during sod establishment due to increased amounts of nutrients from the compost. Organic compost was reported to enhance turfgrass quality in many previous studies (Loschinkohl and Boehm, 2001; Norrie and Gosselin, 1996; Schumann et al., 1993).

The changes (gain and loss) of $\mathrm{N}$ and $\mathrm{P}$ nutrients and their availability are regulated and controlled by soil organic matter, which is one of the most important factors in the storage of nutrients in these nutrient-poor sandy soils (Wezel et al., 2000). One element could be added to the effects of compost is that soils with organic amendments had near neutral $\mathrm{pH}$ values (6.5-8.1), which represent a range favorable for turfgrass root growth (Landschoot, 1996). 
Table (4): Average clippings fresh weight per month and root/shoot ratio, total chlorophyll, and quality score of Bermudagrass treated with NPK fertilizer and compost at the end of the two seasons 2008/2009 and 2009/2010.

\begin{tabular}{|c|c|c|c|c|c|c|c|c|}
\hline & \multicolumn{2}{|c|}{$\begin{array}{c}\text { Average fresh } \\
\text { weight of clipping } \\
\left(\mathrm{g} / \mathrm{m}^{2} / \mathrm{month}\right)\end{array}$} & \multicolumn{2}{|c|}{ Root/shoot ratio } & \multicolumn{2}{|c|}{$\begin{array}{l}\text { Total chlorophyll } \\
(\mathrm{mg} / 100 \mathrm{~g} \mathrm{fw})\end{array}$} & \multicolumn{2}{|c|}{ Quality score } \\
\hline & $\begin{array}{l}2008 / \\
2009\end{array}$ & $\begin{array}{l}2009 / \\
2010\end{array}$ & $\begin{array}{l}2008 / \\
2009\end{array}$ & $\begin{array}{l}2009 / \\
2010\end{array}$ & $\begin{array}{c}2008 / \\
2009\end{array}$ & $\begin{array}{l}2009 / \\
2010\end{array}$ & $\begin{array}{l}2008 / \\
2009\end{array}$ & $\begin{array}{l}2009 / \\
2010\end{array}$ \\
\hline Control & 67.88 & 69.91 & 0.39 & 0.40 & 1.17 & 1.19 & 5.5 & 5.6 \\
\hline C1 & 69.5 & 71.5 & 0.40 & 0.41 & 1.24 & 1.26 & 5.5 & 5.7 \\
\hline $\mathrm{C2}$ & 69.5 & 71.6 & 0.41 & 0.42 & 1.28 & 1.32 & 5.6 & 5.8 \\
\hline M1 & 83.67 & 86.18 & 0.40 & 0.42 & 1.65 & 1.72 & 6.24 & 6.43 \\
\hline M2 & 96.39 & 99.28 & 0.40 & 0.42 & 1.67 & 1.75 & 6.43 & 6.62 \\
\hline M3 & 107.95 & 111.19 & 0.41 & 0.44 & 1.7 & 1.82 & 6.80 & 7.00 \\
\hline$M 1+C 1$ & 83.7 & 87.9 & 0.40 & 0.41 & 1.7 & 1.73 & 6.2 & 6.3 \\
\hline $\mathrm{M} 1+\mathrm{C} 2$ & 95.5 & 98.4 & 0.42 & 0.43 & 1.78 & 1.82 & 6.5 & 6.7 \\
\hline M2+C1 & 96.4 & 99.3 & 0.42 & 0.43 & 1.8 & 1.85 & 6.48 & 6.6 \\
\hline $\mathrm{M} 2+\mathrm{C2}$ & 106.0 & 109.1 & 0.43 & 0.45 & 1.82 & 1.89 & 6.6 & 6.8 \\
\hline M3+C1 & 113.3 & 111.6 & 0.43 & 0.45 & 1.9 & 2.00 & 7.0 & 7.1 \\
\hline $\mathrm{M} 3+\mathrm{C} 2$ & 145.4 & 151.2 & 0.47 & 0.51 & 1.9 & 2.03 & 7.2 & 7.4 \\
\hline LSD 5\% & 6.8 & 8.2 & 0.03 & 0.05 & 0.12 & 0.16 & 0.4 & 0.5 \\
\hline
\end{tabular}

Total carbohydrates, nitrogen, phosphorus, and potassium percentages:

In the first and second seasons, at the end of the experiment, total carbohydrates, nitrogen, potassium, and phosphorus \% (Table, 5 ) were all the highest in Bermudagrass which received high NPK fertilizer combined with either compost treatments $(\mathrm{M} 3+\mathrm{C} 2$ and $\mathrm{M} 3+\mathrm{C} 1)$, and were significantly higher in all measurements than high NPK fertilizer treatment alone (M3). Similarly, results showed that applications of composted biosolids at increasing rates resulted in a linear increase in tall fescue foliar $\mathrm{N}$ concentrations (Sikora et al., 1980; Tester et al., 1982; Tester, 1989). Sakr et al., (2008) reported that combining sewage sluge compost $(0.01 \mathrm{~m} 3 / \mathrm{m} 2)$ with the highest rate of conventional NPK fertilizer $(55.6 \mathrm{~g} / \mathrm{m} 2 / \mathrm{month})$ resulted in the highest values for vegetative growth parameters as well as the contents of $\mathrm{N}, \mathrm{P}, \mathrm{K}, \mathrm{Fe}$, and $\mathrm{Zn}$ in clippings.

The results of this experiment showed that higher inorganic fertilizer rate and the incorporation of $3 \mathrm{~kg}$ of the bioorganic compost resulted in better growth and quality of Bermudagrass grown in sandy soils. However, quality did not exceed 7.5 score and even less than that score throughout most of the year. This is supported by the fact that $\mathrm{N}, \mathrm{P}$, and $\mathrm{K}$ contents of the clippings in best case were less than those reported by Voigt et al., (2006). This indicates that turfgrasses in this type of soils require more attention regarding quantity, type, methods of soluble fertilizer application, and amount and type of soil amendments used. 
Table (5): Percentages of the total carbohydrates, nitrogen , phosphorus, and potassium in the clippings of Bermudagrass treated with NPK fertilizer and compost at the end of the two seasons 2008/2009 and 2009/2010.

\begin{tabular}{|c|c|c|c|c|c|c|c|c|}
\hline & $\begin{array}{c}\text { Total carbohydrates } \\
\text { (\%) }\end{array}$ & \multicolumn{2}{c|}{ N\% } & \multicolumn{2}{c|}{ P\% } & \multicolumn{2}{c|}{ K\% } \\
\hline & $\mathbf{2 0 0 8 / 2 0 0 9}$ & $\mathbf{2 0 0 9 / 2 0 1 0}$ & $\mathbf{2 0 0 8 / 2 0 0 9}$ & $\mathbf{2 0 0 9 / 2 0 1 0}$ & $\mathbf{2 0 0 8 / 2 0 0 9}$ & $\mathbf{2 0 0 9 / 2 0 1 0}$ & $\mathbf{2 0 0 8 / 2 0 0 9}$ & $\mathbf{2 0 0 9 / 2 0 1 0}$ \\
\hline Control & 19.5 & 19.9 & 1.15 & 1.17 & 0.07 & 0.09 & 1.11 & 1.13 \\
\hline C1 & 20.5 & 20.9 & 1.30 & 1.33 & 0.09 & 0.09 & 1.16 & 1.18 \\
\hline C2 & 21.2 & 21.6 & 1.32 & 1.35 & 0.08 & 0.08 & 1.18 & 1.20 \\
\hline M1 & 21.9 & 22.3 & 1.40 & 1.43 & 0.09 & 0.09 & 1.20 & 1.22 \\
\hline M2 & 23.6 & 24.1 & 1.45 & 1.48 & 0.13 & 0.12 & 1.26 & 1.29 \\
\hline M3 & 24.2 & 24.7 & 1.60 & 1.63 & 0.12 & 0.14 & 1.43 & 1.46 \\
\hline M1+C1 & 21.8 & 22.7 & 1.47 & 1.53 & 0.18 & 0.19 & 1.44 & 1.50 \\
\hline M1+C2 & 22.4 & 23.3 & 1.48 & 1.54 & 0.19 & 0.20 & 1.50 & 1.56 \\
\hline M2+C1 & 23.7 & 24.6 & 1.52 & 1.58 & 0.22 & 0.23 & 1.52 & 1.58 \\
\hline M2+C2 & 23.9 & 24.9 & 1.58 & 1.64 & 0.23 & 0.24 & 1.54 & 1.60 \\
\hline M3+C1 & 24.1 & 25.1 & 1.73 & 1.80 & 0.24 & 0.25 & 1.62 & 1.68 \\
\hline M3+C2 & 24.9 & 25.9 & 1.79 & 1.86 & 0.29 & 0.27 & 1.70 & 1.78 \\
\hline LSD 5\% & 1.3 & 1.2 & 0.11 & 0.13 & 0.1 & 0.09 & 0.06 & 0.11 \\
\hline
\end{tabular}

\section{REFERENCES}

Alshammary, S.F.; Y.L. Qian and. S.J. Wallner. (2004). Growth response of four turfgrass species to salinity. Agricultural Water Management, 66: 97-111.

Angle, J.S.; J.R. Hall and D.C. Wolf. (1981). Turfgrass growth aided by sludge compost. Biocycle, 2: 40-43.

Beard, J.B. (1973). Turfgrass: Science and Culture. Prentice-Hall, Englewood Cliffs. NJ, USA.

Bigelow, C.A.; D.C. Bowman, and D.K. Cassel. (2001). Nitrogen leaching in sand-based rootzones amended with inorganic soil amendments and sphagnum peat. J. Am. Soc. Hort. Sci., 126(1): 151-156.

Bigelow, C. A.; D. C. Bowman and D. K. Cassel. (2004). Physical properties of three sand size classes amended with inorganic materials or sphagnum peat moss for putting green rootzones. Crop Sci., 44: 900907.

Callahan, L.M., and J.R. Overton. (1978). Effects of lawn management practices in a Bermudagrass turf. Tenn. Farm Home Sci., 108:37-40.

Carrow, R.N., B.J. Johnson and R.E. Burns. (1987). Thatch and quality of Tifway Bermudagrass turf in relation to fertility and cultivation. Agron. J., 79: 524-530.

Chantigny, M.H.; D.A .Angers and P. Rochette. (2002). Fate of carbon and nitrogen from animal manure and crop residues in wet and cold soils. Soil Biol.\& Biochem., 34: 509-517.

Cisar, J.L. and G.H. Snyder. (1992). Sod production on a solid-waste compost over plastic. J. Hortic. Sci., 27: 219-222. 
Duble, R.L. (2010). Bermudagrass "The Sports Turf of the South". Texas AgriLife Extension Service, Texas A\&M System. http://aggiehorticulture.tamu.edu/archives/parsons/turf/publications/bermuda.html

Dubois, M.; K.A. Gilles; J.K. Hamiltton; P.A. Rebers and F. Smith. (1956). Colorimetric methods of determination of sugars and related substances. Anal. Chem., 28: 350-354.

Franzluebbers, A.J. ( 2002). Water infiltration and soil structure related to organic matter and its stratification with depth. Soil \& Tillage Res., 66: 97-105.

Garling, D.C. and M.J. Boehm. (2001). Temporal effects of compost and fertilizer applications on nitrogen fertility of golf course turfgrass. Agron. J., 93: 548-555.

Geron, C.A.; T.K. Danneberger; S.J. Traina,;T.J. Logan and J.R. Street. (1993). The effects of establishment methods and fertilization practices on nitrate leaching from turfgrass. J. Environ. Qual., 22(1): 119-125.

Ginting, D.; A. Kessavalou; B. Eghball and J.W. Doran. (2003). Greenhouse gas emissions and soil indicators four years after manure and compost applications. J. Environ. Qual., 32: 23-32.

Gregorich, E.G.; P. Rochette; S. McGuire; B.C. Liang and R. Lessard. (1998). Soluble organic carbon and carbon dioxide fluxes in maize fields receiving spring-applied manure. J. Environ. Qual., 27: 209-214.

Grigg, G. T. (1999). Foliar Nutrition of Turfgrasses. Golf Course Manag. 67:65-68.

Habteselassie, M.Y.; J.M. Stark; M B. E.iller; S.G. Thacker and J.M. Norton. (2006). Gross nitrogen transformations in an agricultural soil after repeated dairy-waste application. J. Am. Soc. Soil Sci., 70: 1338-1348.

Hull, R.J. 1996. Nitrogen usage by turfgrasses. Turfgrass Trends, 5:6-14.

Jackson, M.L. (1973). Soil Chemical analysis. Prentice-Hall of India, New Delhi.

Landschoot, P. (1996). Using Composts to Improve Turf Performance. Publications Distribution Center, Pennsylvania State University Cooperative Extension, University Park, PA.

Landschoot, P.J. and A.S. McNitt. (1994). Improving turf with compost. Biocycle, 35: 54-57.

Landschoot, P.J. and D.V. Waddington. (1987). Response of turfgrass to various nitrogen fertilizers. J. Am. Soc. Soil Sci., 51: 225-230.

Loschinkohl, C. and M.J., Boehm. (2001). Composted biosolids incorporation improves turfgrass establishment on disturbed urban soil and reduces leaf rust severity. HortScience, 36: 790-794.

Marquard, R.D. and G.L. Timpton. (1987). Relationship between extrable chlorophyll and in situ method to estimate leaf green. HortSci., 22(6): 1327-1329.

Marshall, S.B.; M.D. Mullen; M.L. Cabrera; C.W. Wood; L.C. Braun and E.A. Guertal. ( 2001). Nitrogen budget for fescue pastures fertilized with broiler litter in Major Land Resource Areas of the southeastern US. Nutr. Cycl. Agroecosys., 59: 75-83. 
Norrie, J. and A. Gosselin. (1996). Paper sludge amendments for turfgrass. HortScience, 31:957-960.

Paswan, L. and R. K. Machahary. (2000). Effect of nitrogen on bahiagrass. Journal of Ornamental Horticulture (New Series), 3 (2): 87-90.

Razmjoo, K. and S. Kaneko. (1993). Effect of fertility ratio son growth and turf quality of perennial ryegrass (Lolium perenne) in winter. J. Plant Nutr., 16 (8):1531-1538.

Sakr, W.R.; M.M. Hussein and M.M. Kamel. (2008). Response of Japanese lawngrass of (Zoysia japonica, Steud.) grown in sandy soil to some soil amendments and fertilization treatments. American-Eurasian J. Agric \& Environ. Sci., 3 (3): 298-313.

SAS. (1998). SAS User's Guide: Statistics, 1982 Edition. SAS Institute Inc. Box 800, Cary, NC 27511.

Shuman, L.M. (2002). Phosphorus and nitrate nitrogen in runoff following fertilizer application to turfgrass. J. Environ. Qual., 31:1710-1715.

Schumann, G.L.; H. Soares ; C.M. Holden and M.S. Switzenbaum. (1993). Relationship of traditional parameters of compost stability to turfgrass quality. Environmental Technology, 14 (3): 257-263.

Sikora, L. J.; C. F. Tester; J.M. Taylor and J. F. Parr. (1980). Fescue yield response to sewage sludge compost amendments. Agron. J., 72: 7984.

Sims, J.T. (1990). Nitrogen mineralization and elemental availability in soils amended with composted sewage sludge. J. Environ. Qual., 19: 669675.

Snyder, G.H. and J.L. Cisar. (2000). Nitrogen/potassium fertilization ratios for Bermudagrass turf. Crop Sci., 40:1719-1723.

Starrett, S.K.; N.E. Christians and T.A. Austin. (1995). Fate of amended urea in turfgrass biosystems. Commun. Soil Sci. Plant Anal., 26 : $1595-1606$.

Tester, C.F. (1989). Tall fescue growth in greenhouse, growth chamber, and field plots amended with sewage-sludge compost and fertilizer, Soil Sci. , 148 (6): $452-458$

Tester, C.F., L.J. Sikora, J.M. Taylor and J.F. PARR. (1982). Nitrogenutilization by tall fescue from sewage-sludge compost amended soils. Agron. J., 74 (6): 1013-1018.

Totten, F.W. (2007), Long-term evaluation of liquid vs. granular nitrogen fertilization on creeping bentgrass [Agrostis stoloniferous L. var. palustris Huds.] and hybrid Bermudagrass [Cynodon dactylon (L.) Pers. $x$ C. transvaalensis Burtt-Davy] performance. Ph.D. Thesis. Plant and Environmental Science, Clemson University, USA. UMI Microform: 3239585. ProQuest Information and Learning Company, Ann Arbor, MI, USA.

Trenholm, L. E.; R.N. Carrow and R.R. Duncan. (2001). Wear tolerance, growth, and quality of seashore paspalum in response to nitrogen and potassium. Hort Sci., 36:780-783. 
Van Auken, O.W. and J.K. Bush. (1997). The importance of neighbors, soil $\mathrm{pH}$, phosphorus and nitrogen for the growth of two C4 grasses. Int. J. Plant Sci., 158:325-331.

Voigt T.; T. Fermanian and D. Wehner. (2006). Turfgrass Fertilization. http://turfgrassmanagement.psu.edu/turfgrassfertilizationbasics.cfm

Weber J.; A. Karczewska; J. Drozd; M. Licznar; S. Licznar; E. Jamroz, and A. Kocowicz. (2007). Agricultural and ecological aspects of a sandy soil as affected by the application of municipal solid waste composts Soil Biol. \& Biochem., 39: 1294-1302.

Wezel, A.; J.L. Rajot and C. Herbrig. (2000). Influence of shrubs on soil characteristics and their function in Sahelian agro-ecosystems in semiarid Niger. J. Arid Environ., 44:. 383-398.

Wright A.L.; T.L. Provin; F.M. Hons; D.A. Zuberer and R.H. White. (2008). Compost impacts on dissolved organic carbon and available nitrogen and phosphorus in turfgrass soil. Waste Management, 28: 10571063.

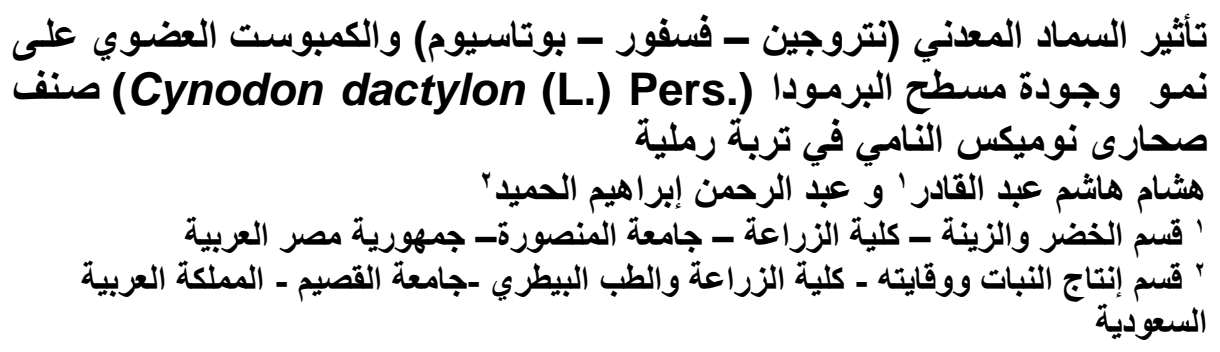

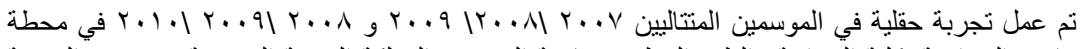

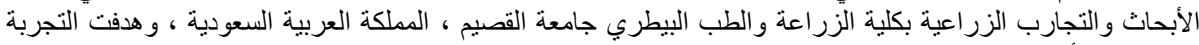

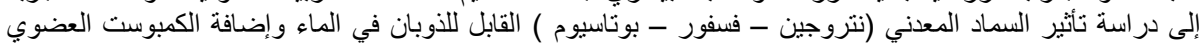

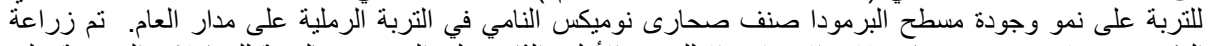

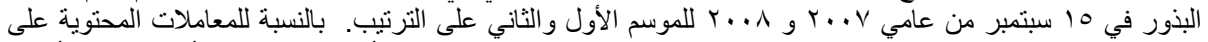

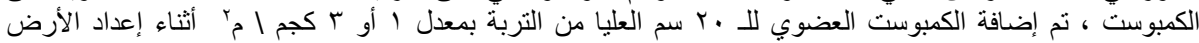

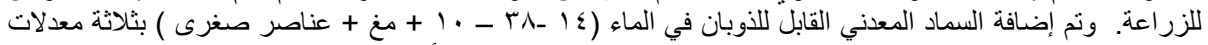

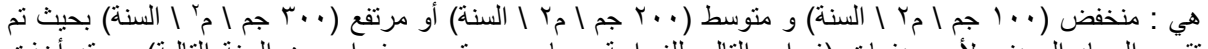

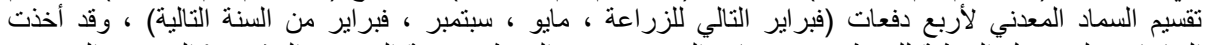

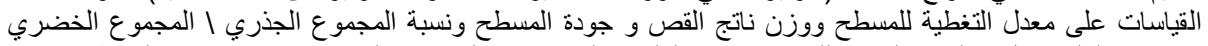

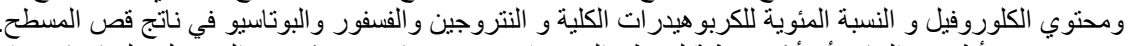

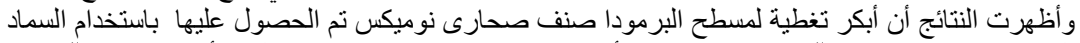

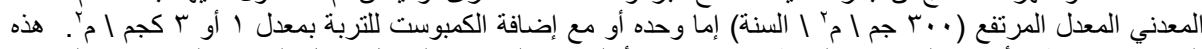

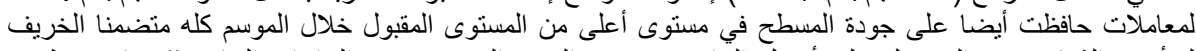

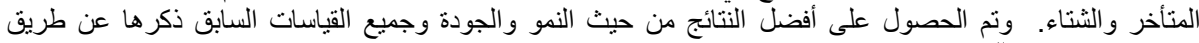

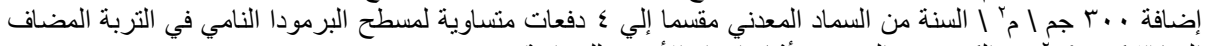

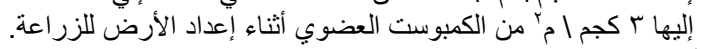

كلية الزراعة - جامعة المنصورة

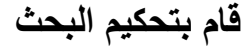
كلية الزراعة - جامعة كفر الثيخ

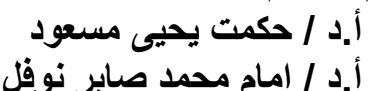

